Open Access

\title{
Residential satisfaction in gated communities according to stages in the life cycle with reference to Cairo, Egypt
}

\author{
Fatma Osama Osman ${ }^{1 *}$, Yasser M. Moustafa ${ }^{2}$ and Amgad Aly Fahmy ${ }^{3}$
}

\author{
* Correspondence: fatma.o.b. \\ osman@gmail.com \\ ${ }^{1}$ Department of Architecture and \\ Environmental Design, College of \\ Engineering, Arab Academy for \\ Science, Technology \& Maritime \\ Transport, El-Moshir Ahmed Ismail \\ St. off Salah Salem St, PO Box 2033, \\ Cairo, Egypt \\ Full list of author information is \\ available at the end of the article
}

\begin{abstract}
The objective of the study is to investigate, in the Egyptian context, residential satisfaction in gated communities (GCs) in relation to stages in the life cycle. The aim is to identify possible differences between the different stages in the life cycle in terms of the most important predictors of overall residential satisfaction. The study relies on a survey questionnaire administered to a sample of residents of Al-Rehab GC in Cairo, Egypt $(n=131)$. The sample was divided into four life cycle stage groups: young singles (YS) ( $n=36)$, heads of young family households (YF) $(n=41)$, heads of households with older children (OC) $(n=34)$, and empty nesters (EN) $(n=$ 20). Statistical analysis does indeed reveal differences between stages in the life cycle in relation to the most important components of residential satisfaction. In particular, for YF and OC, the social environment within the GC was the most important predictor of overall residential satisfaction. For these two life cycle groups, issues related to the needs and safety of their children were also important. In contrast, for EN, the social environment and characteristics of the area around the dwelling appeared to be much less important than for other groups. For EN, satisfaction with the dwelling unit itself was shown to be the most important predictor of overall residential satisfaction.
\end{abstract}

Keywords: Residential satisfaction, Gated communities, Stages in the life cycle, Cairo, Egypt

\section{Introduction}

In Cairo, like in many cities around the world, gated communities (GCs) are a relatively new, but rapidly spreading housing typology [1-3]. Increasing numbers of residents are opting to move to GCs, attracted by expectations of better lifestyle, more privacy and security $[1,4-11]$. The evaluation of existing GCs developments is certainly important for guiding both the design of future projects and urban policy making [12-16]. Residential satisfaction is a concept that is often used to evaluate residential environments from the perspective of the residents themselves [17-20]. Because residential needs and expectations typically change with age and household

(c) The Author(s). 2021 Open Access This article is licensed under a Creative Commons Attribution 4.0 International License, which permits use, sharing, adaptation, distribution and reproduction in any medium or format, as long as you give appropriate credit to the original author(s) and the source, provide a link to the Creative Commons licence, and indicate if changes were made. The images or other third party material in this article are included in the article's Creative Commons licence, unless indicated otherwise in a credit line to the material. If material is not included in the article's Creative Commons licence and your intended use is not permitted by statutory regulation or exceeds the permitted use, you will need to obtain permission directly from the copyright holder. To view a copy of this licence, visit http://creativecommons.org/licenses/by/4.0/. The Creative Commons Public Domain Dedication waiver (http://creativecommons.org/publicdomain/zero/1.0/) applies to the data made available in this article, unless otherwise stated in a credit line to the data. 
characteristics $[9,17,21]$, it is essential to investigate residential satisfaction in relation to stages in the life cycle. While some evaluations of GCs in Cairo have already been conducted $[6,8,10,22,23]$, to date; studies have not focused on differences in residential satisfaction related to stages in the life cycle. Accordingly, the objective of the current study is to investigate, in the Egyptian context, residential satisfaction in GCs according to stages in the life cycle.

\section{The GC phenomenon}

The literature provides several definitions of GCs [1, 2, 4, 5, 7, 12, 14, 15, 24, 25]. However, most of these definitions agree that GCs are residential developments that may differ in size, configuration, and layout, but they are mainly surrounded by walls or any kind of artificial or natural fences, with gates or controlled entrances to regulate the access of non-residents. The literature also distinguishes between different types of GCs. In particular, Blakely and Snyder classified GCs based on the motivations of residents, into (1) lifestyle communities, (2) prestige (elite) communities, and (3) security zone communities [4].

The rapid spread of the GC phenomenon in cities all around the world can be explained in large parts by the multiple reasons for which urban residents decide to move to GCs. One of these reasons is a general perception of the presence of urban crime and the desire for greater levels of security $[4,5,11,24]$. People also opt to move to GCs seeking better lifestyles, higher living standards, prestige, and sense of community [1, 4, 15, 25-27]. Indeed, advertisements for GCs developments typically promise a healthy life, high-quality services and facilities, peace, quietness, and increased privacy $[1,4,5,9,11]$. In addition, the purchase of a home in a GC is often seen as a particularly good real estate investment $[9,11,24]$. In the Egyptian context, people tend to be attracted to GCs for the very same reasons $[6,10,22,28]$.

\section{The concept of residential satisfaction}

Residential satisfaction refers to the individuals' evaluation of the conditions of their residential environment, in relation to their needs, expectations, and achievements [17, 29]. It is the way that residents evaluate the place in which they live $[9,18]$. Measuring residential satisfaction has become an important indicator for judging the success of residential developments [9]. It is a key for designing successful future housing developments and implementing effective housing policies [20]. Residential satisfaction is a multidimensional concept, that depends on satisfaction with the different components and aspects of the residential environment $[15,19,20,30]$. Residential satisfaction needs to be conceived and evaluated through the features and characteristics of both the physical and social environments [20]. The physical components of residential satisfaction concern both physical conditions within the dwelling and the conditions of the neighborhood surrounding the dwelling [21,31]. The social components are also important dimensions of residential satisfaction. They include social interaction and relations with neighbors [7, 32, 33].

\section{Residential satisfaction in GCs}

Several studies have investigated residential satisfaction in GCs. A number of these studies show that life in GCs is sometimes associated with unfulfilled expectations and 
disappointments with such issues, as the high cost of maintenance and of provided services and great social isolation $[5,14,25,26,32]$. However, most studies show that residents are generally satisfied with life in GCs. For example, a study conducted in Istanbul, Turkey, suggests that residents of GCs tend to be satisfied with greater levels of security, variety of facilities, accessibility to green open areas, and levels of maintenance of the housing areas [15]. A study conducted in Malaysia reveals that the relatively high levels of residential satisfaction among residents of GCs are particularly associated with financial benefits, social status, and lifestyle facilities [9]. A study conducted in Kenya also shows that residents of GCs tend to be satisfied with their residential environment and in particular with the enhanced security, improved quality of life, and greater sense of community [32]. Similarly, in the Egyptian context, two studies conducted in Cairo [8] and Alexandria [10] indicate that residents tend to be satisfied with their move to GCs, particularly in relation to better lifestyle, increased prestige, and the preservation of their real estate investment. Despite the relatively large number of studies that have investigated residential satisfaction in GCs, to date residential satisfaction in GCs in relation to stages in the life cycle has not really been addressed, in general, but particularly in the Egyptian context.

\section{Residential satisfaction and stages in the life cycle}

The concept of 'stages in the life cycle' is a concept that is used in housing studies to describe a number of socio-demographic characteristics of individuals or households such as age, marital status, and number and ages of children [20,34-36]. The housing literature shows that housing needs, expectations, choices and ultimately housing satisfaction are strongly related to stages in the life cycle [19, 34, 36, 37]. For example, McCarthy showed how housing characteristics and choices are greatly determined according to stages in the life cycle [34]. Also, Speare has demonstrated the relationship between stages in the life cycle, housing consumption, and local mobility [38]. In addition, Grigolon found that differences in residential satisfaction can be explained by residents' needs, constraints, or preferences, which are, in fact, all strongly related to life cycle stages [39]. Consequently, the objective of the current study is to investigate, in the Egyptian context, residential satisfaction in GCs in relation to stages in the life cycle. It aims to identify possible differences in residential satisfaction between different stages in the life cycle.

\section{Method}

\section{Research design}

To fulfill the research objectives, the study adopts a correlational research design [40]. It relied primarily on a survey questionnaire designed to assess the different dimensions of residential satisfaction. The questionnaire was administered in January 2020 to a sample of residents of phases 1 and 2 in Al-Rehab GC in New Cairo. Al-Rehab GC is composed of ten phases set on an area of 10 million $\mathrm{m}^{2}$. The GC's current population is about 110,000 residents [41]. This particular GC was selected for the study for several reasons. First, Al-Rehab is one of the oldest GCs in Greater Cairo. Its development started in 1997. Consequently, many of Al-Rehab phases, particularly phases 1 and 2 have been inhabited for more than 10 years. Second, Al-Rehab features a large variety 
of residential unit types, such as separate villas, twin villas, town houses, and apartment units of different areas [42]. As a result, Al-Rehab GC is characterized by a relative socio-demographic diversity among residents, including diversity in terms of stages in the life cycle. It should be noted, however, that Al-Rehab cannot be considered to represent all GCs in Cairo. It is more representative of the larger lifestyle GCs with relative self-sufficiency in terms of services and shopping facilities [4, 23, 42]. Al-Rehab, indeed, is considered to be a self-sufficient community. It offers a range of facilities and services from the basic needs to comprehensive services for entertainment. It features large green areas, commercial markets, shopping and commercial malls, cafes, restaurants, cinema theaters, a sportive and social club, banking facilities, educational facilities, and health care services [41, 42].

\section{Design of survey questionnaire}

The questionnaire was designed in seven sections. The first section inquired about the relevant socio-demographic characteristics of respondents in order to be able to classify them in different stage of the life cycle groups. These characteristics included gender, age, educational attainment, marital status, number and age of children, and number of children still living at home with the respondent. Questions also inquired about how long the respondents have been living in Al-Rehab, type of dwelling, area of dwelling, location of the respondents' work or school and location of children's school, whether inside or outside of Al-Rehab GC. This section also featured a question that inquired about reasons for choosing to live in a GC. It asked the respondents to select the three main reasons among a number of choices (lifestyle-security-comfort-privacy-healthy environmentquietness-access to services and facilities). The second section included a number of questions designed to assess 'overall residential satisfaction'. The main question asked respondents to rate their satisfaction with life in a GC. Then, two other questions were included to further confirm ratings of overall residential satisfaction. One asked the respondents the extent to which they would recommend Al-Rehab as a favorable place to live and reside. The other one asked them to indicate where they would prefer to live if they were not living in Al-Rehab, in another GC or not in a GC. The following five sections were designed to assess the different components or determinants of overall residential satisfaction (see Table 1). Three of these components, 'dwelling satisfaction', 'neighborhood satisfaction', and 'satisfaction with the social environment', are directly derived from the residential satisfaction literature [18-20,32,33]. Two other components of overall residential satisfaction, 'sense of security', and 'satisfaction with ease of mobility and access to services' also needed to be emphasized to better adapt the concept of residential satisfaction to the particular case of GCs $[13,15,16]$.

Each of these five sections included first a question asking respondents to rate the overall satisfaction with the component investigated (e.g., rate overall satisfaction with your dwelling unit or rate overall satisfaction with your social life as a resident of AlRehab). Then, as detailed in Table 1, the five sections included a number of questions asking respondents to rate their satisfaction with various aspects of the different components investigated.

As is most common in questionnaires designed to assess residential satisfaction [13], Sections 2 through 7 relied primarily on rating questions and a 5-point Likert scale 
Table 1 Components of overall residential satisfaction and their various aspects investigated

\begin{tabular}{|c|c|}
\hline Components of overall residential satisfaction & Various aspects investigated \\
\hline \multirow{5}{*}{$\begin{array}{l}\text { Section } 3 \text { of questionnaire } \\
\text { Dwelling satisfaction }\end{array}$} & Area of dwelling \\
\hline & Views from dwelling \\
\hline & Privacy in dwelling \\
\hline & Quietness in and around dwelling \\
\hline & Car parking spaces \\
\hline \multirow{6}{*}{$\begin{array}{l}\text { Section } 4 \text { of questionnaire } \\
\text { Neighborhood satisfaction }\end{array}$} & Attractiveness \\
\hline & Cleanliness \\
\hline & Maintenance \\
\hline & Green areas \\
\hline & Play areas for children \\
\hline & Possibility of walking around dwelling \\
\hline \multirow{5}{*}{$\begin{array}{l}\text { Section } 5 \text { of questionnaire } \\
\text { Sense of security }\end{array}$} & Safety from house burglary \\
\hline & Walking alone around dwelling \\
\hline & Playing of children around dwelling \\
\hline & Safety from traffic accidents \\
\hline & Presence of security at the main gates \\
\hline \multirow{7}{*}{$\begin{array}{l}\text { Section } 6 \text { of questionnaire } \\
\text { Mobility and access to services }\end{array}$} & Going in and out of Al-Rehab \\
\hline & Access to public transportation/taxis/uber \\
\hline & Going to work/school \\
\hline & Buying daily needs \\
\hline & Access to health-care services \\
\hline & Going to the club of Al-Rehab \\
\hline & Going to recreational places \\
\hline \multirow{7}{*}{$\begin{array}{l}\text { Section } 7 \text { of questionnaire } \\
\text { Satisfaction with the social environment }\end{array}$} & Meeting family and friends \\
\hline & Social compatibility \\
\hline & Sense of community \\
\hline & Sense of belonging \\
\hline & Social interaction \\
\hline & Cooperation and support \\
\hline & Participation in management \\
\hline
\end{tabular}

response format: "1" = very unsatisfied, "2" = unsatisfied, "3" = neutral, "4" = satisfied and " 5 " = very satisfied. The questionnaire was pilot-tested to make sure that the questions were clear and that the completion time was reasonable. The pilot-testing led to the refined final version of the questionnaire.

\section{Sampling and respondents' characteristics}

Sampling relied primarily on a combined convenience and snow ball sampling approach $[40,43,44]$. The questionnaire was e-mailed first to a number of acquaintances of the researchers living in Al-Rehab, who, in turn, distributed the questionnaire to their relatives and friends within the GC. The questionnaire was also posted on a number of Al-Rehab social media groups. A total of 131 residents of Al-Rehab responded to the questionnaire. Table 2 presents the main demographic characteristics of the 
respondents. These demographic characteristics, along with 'number of children', 'age of children' and 'how many children still living at home with the respondent', helped classify the respondents into different stages of the life cycle. The stages of the life cycle considered were derived from the literature [34, 37, 45-47] and adapted to better fit the Egyptian context and the particular characteristics of respondents. Four stages in the life cycle were thus defined:

1) Young singles (YS) $(n=36)$ : respondents aged 15 to 24 , or 25 to 34 ( 2 respondents), not married, living with their parents and who tended to be school or college students.

2) Heads of young family households (YF) $(n=41)$ : respondents aged 25 to 44 , married or divorced (1 respondent) with no children, or with young children (younger than 13 years).

Table 2 Main demographic characteristics of the respondents $(n=131)$

\begin{tabular}{|c|c|c|}
\hline \multicolumn{2}{|l|}{ Characteristics } & \multirow{2}{*}{$\begin{array}{l}f(\%) \\
53(40 \%)\end{array}$} \\
\hline Gender & Males & \\
\hline & Females & $78(60 \%)$ \\
\hline \multirow[t]{5}{*}{ Age } & $(16-24)$ & $34(26 \%)$ \\
\hline & $(25-34)$ & $30(23 \%)$ \\
\hline & $(35-44)$ & $29(22 \%)$ \\
\hline & $(45-54)$ & $16(12 \%)$ \\
\hline & $(>54)$ & $22(17 \%)$ \\
\hline \multirow[t]{5}{*}{ Marital status } & Single living with parents & $36(27.5 \%)$ \\
\hline & Single not living with parents & $0(0 \%)$ \\
\hline & Married & $89(68 \%)$ \\
\hline & Divorced & $4(3 \%)$ \\
\hline & Widow & $2(1.5 \%)$ \\
\hline \multirow[t]{4}{*}{ Duration of living in Al-Rehab } & Less than 1 year & $10(7.5 \%)$ \\
\hline & $(1-5)$ & $37(28 \%)$ \\
\hline & $(6-10)$ & $48(37 \%)$ \\
\hline & More than 10 years & $36(27.5 \%)$ \\
\hline \multirow[t]{2}{*}{ Type of dwelling } & Apartment & $111(85 \%)$ \\
\hline & Villa & $20(15 \%)$ \\
\hline \multirow[t]{5}{*}{ Area of dwelling } & $\left(90-120 m^{2}\right)$ & $30(23 \%)$ \\
\hline & $\left(130-160 \mathrm{~m}^{2}\right)$ & $61(46.5 \%)$ \\
\hline & $\left(170-200 m^{2}\right)$ & $14(11 \%)$ \\
\hline & $\left(200-250 \mathrm{~m}^{2}\right)$ & $10(7.5 \%)$ \\
\hline & (more than $250 \mathrm{~m}^{2}$ ) & $16(12 \%)$ \\
\hline \multirow{3}{*}{$\begin{array}{l}\text { Location of respondent' } \\
\text { work or school }\end{array}$} & Outside Al-Rehab & $90(68.5 \%)$ \\
\hline & Inside Al-Rehab & $20(15.5 \%)$ \\
\hline & Not relevant* & $21(16 \%)$ \\
\hline \multirow{3}{*}{$\begin{array}{l}\text { Location of respondents' } \\
\text { children school }\end{array}$} & Outside Al-Rehab & $46(35 \%)$ \\
\hline & Inside Al-Rehab & $13(10 \%)$ \\
\hline & Not relevant** & $72(55 \%)$ \\
\hline
\end{tabular}

* Respondents are retired or not working

**Respondents have no children or have children who are not school age 
3) Heads of households with older children (OC) $(n=34)$ : respondents above the age of 34 , married, divorced (3 respondents), or widowed (1 respondent) with children above the age of 13 still living at home.

4) Empty nesters $(\mathrm{EN})(n=20)$ : respondents above the age of 44, married or widowed (1 respondent) whose children are no longer living at home.

According to these operational definitions of the different life cycle stages, YS and OC in particular may represent the same households. However, in this study, the unit of analysis is not the household but individuals in different stages in the life cycle (for a similar approach see [46]). The logic is that young persons and their parents, even if living in a same household, may have different needs and expectations in relation to the residential environment. Accordingly, they may have different levels of residential satisfaction and different determinants of residential satisfaction.

\section{Data analysis}

Questionnaire responses were analyzed using SPSS to compare between the different stage in the life cycle groups. First, descriptive statistics were calculated and were used to organize and present the data as well as to analyze frequency distributions for the answers of the questionnaire. Then several inferential statistical tests were performed. Mean values of ratings for overall residential satisfaction and for its different components were compared across life cycle groups using the analysis of variance ANOVA. Non-parametric Spearman correlations were conducted to determine the correlations between each of the different components of residential satisfaction and its aspects. Multiple linear regression analysis (MLRA) was conducted to identify, for each life cycle group, the significant predictors of overall residential satisfaction and of its components.

\section{Results}

\section{Main reasons for choosing to live in a $\mathrm{GC}$}

For respondents as a whole, the choices of main reasons for opting to live in a GC were, from the most to the least frequently selected, 'quietness', 'access to services and facilities', 'lifestyle', 'safety and security', 'comfort', 'healthy environment', 'privacy', and finally 'location' which was selected by only two of the respondents (see Table 3). The table also shows the choices of the different life cycle groups. For YS, the most frequently selected choices were 'quietness', 'comfort', and 'access to services and facilities'. For YF, they were 'access to services and facilities', 'safety and security', and 'lifestyle'. For OC, they were 'access to services and facilities', 'quietness', and 'lifestyle'. Finally, for EN, 'quietness' was clearly the most important reason (selected by $90 \%$ ).

\section{Ratings of overall residential satisfaction and of the different components of residential satisfaction}

As a whole, respondents showed a relatively high level of 'overall residential satisfaction' (satisfaction with life in a GC). Table 4 shows mean ratings for the different life cycle groups. The highest mean was for YF $(M=4.12)$ and the lowest mean was for OC $(M=3.76)$. However, mean differences between the four life cycle groups were 
Table 3 Main reasons for choosing to live in a GC

\begin{tabular}{lllllllll}
\hline \multicolumn{7}{c}{} & \multicolumn{2}{l}{ Reasons for choosing to live in a GC } \\
\cline { 2 - 9 } & Quietness & $\begin{array}{l}\text { Access to } \\
\text { services and } \\
\text { facilities }\end{array}$ & Lifestyle & $\begin{array}{l}\text { Safety } \\
\text { and } \\
\text { security }\end{array}$ & Comfort & $\begin{array}{l}\text { Healthy } \\
\text { environment }\end{array}$ & Privacy & Location \\
\hline All & $75(57.5 \%)$ & 74 & 60 & 58 & 57 & 52 & 29 & 2 \\
respondents & & $(56.5 \%)$ & $(46 \%)$ & $(44.5 \%)$ & $(43.5 \%)$ & $(39.5 \%)$ & $(22 \%)$ & $(1.5 \%)$ \\
YS & $20(55.6 \%)$ & 20 & 12 & 15 & 20 & 19 & 5 & 1 \\
& & $(55.6 \%)$ & $(33.3 \%)$ & $(41.5 \%)$ & $(55.6 \%)$ & $(52.8 \%)$ & $(14 \%)$ & $(2.8 \%)$ \\
YF & 22 & 24 & 23 & 23 & $13(31 \%)$ & 15 & 6 & 1 \\
& $(53.7)$ & $(58.5 \%)$ & $(56 \%)$ & $(56 \%)$ & & $(36.6 \%)$ & $(14.6 \%)$ & $(2.4 \%)$ \\
OC & 15 & 19 & 15 & 15 & 14 & 12 & 11 & 0 \\
& $(44 \%)$ & $(56 \%)$ & $(44 \%)$ & $(44 \%)$ & $(41.2 \%)$ & $(35.3 \%)$ & $(32.4 \%)$ & \\
EN & 18 & 11 & 10 & 5 & $10(50 \%)$ & 6 & 7 & 0 \\
& $(90 \%)$ & $(55 \%)$ & $(50 \%)$ & $(25 \%)$ & & $(30 \%)$ & $(35 \%)$ & \\
\hline
\end{tabular}

minimal and were not found to be statistically significant. The table also shows mean ratings for the different components of residential satisfaction investigated. Ratings for all of these components were relatively high, even if, ratings for 'neighborhood satisfaction' ( $M=4.06$ for respondents as a whole) were slightly higher than for the other components. For all the components of residential satisfaction, mean differences between the four life cycle groups were not found to be statistically significant.

\section{Predictors of dwelling unit satisfaction}

Correlations between 'satisfaction with dwelling unit' and the different aspects of dwelling satisfaction investigated are indicated in Table 5. 'Satisfaction with dwelling unit' was only found to be significantly positively correlated with 'satisfaction with privacy in dwelling' for YS; with 'satisfaction with area of dwelling' and 'satisfaction with views from dwelling' for YF; with 'satisfaction with area of dwelling' and 'satisfaction with quietness in and around dwelling' for OC; and with 'satisfaction with views from dwelling' for EN.

MLRA identified, for each of the four life cycle stages, the best predictors of 'satisfaction with dwelling unit' among the different aspects investigated. As shown in Table 6, for YS, the best and only significant predictor was 'satisfaction with privacy in dwelling'. For YF, the two significant predictors were 'satisfaction with area of dwelling' and 'satisfaction with views from dwelling'. For OC, the two significant predictors were

Table 4 Ratings of overall residential satisfaction and of the components of residential satisfaction (means)

\begin{tabular}{rllllll}
\hline $\begin{array}{l}\text { Components } \\
\text { of residential } \\
\text { satisfaction }\end{array}$ & $\begin{array}{l}\text { Overall } \\
\text { satisfaction }\end{array}$ & $\begin{array}{l}\text { Dwelling } \\
\text { satisfaction }\end{array}$ & $\begin{array}{l}\text { Neighborhood } \\
\text { satisfaction }\end{array}$ & $\begin{array}{l}\text { Sense } \\
\text { of } \\
\text { security }\end{array}$ & $\begin{array}{l}\text { Mobility and } \\
\text { access to } \\
\text { services }\end{array}$ & $\begin{array}{l}\text { Satisfaction with } \\
\text { the social } \\
\text { environment }\end{array}$ \\
\hline $\begin{array}{l}\text { All } \\
\text { respondents }\end{array}$ & 4.00 & 3.81 & 4.06 & 3.64 & 3.70 & 3.98 \\
$\begin{array}{l}\text { Life cycle } \text { YS } \\
\text { stages } 4.08\end{array}$ & 3.86 & 4.00 & 3.67 & 3.92 & 4.00 \\
YF & 4.12 & 3.76 & 4.10 & 3.73 & 3.50 & 4.00 \\
OC & 3.76 & 3.82 & 3.97 & 3.47 & 3.68 & 3.97 \\
EN 4.00 & 3.80 & 4.25 & 3.70 & 3.75 & 3.95 \\
\hline
\end{tabular}


Table 5 Correlations between dwelling unit satisfaction and its different aspects

\begin{tabular}{llllll}
\hline \multirow{2}{*}{$\begin{array}{l}\text { Life cycle } \\
\text { stages }\end{array}$} & \multicolumn{4}{l}{ Aspects of dwelling unit satisfaction } \\
\cline { 2 - 6 } & $\begin{array}{l}\text { Area of } \\
\text { dwelling }\end{array}$ & $\begin{array}{l}\text { Views from } \\
\text { dwelling }\end{array}$ & $\begin{array}{l}\text { Privacy in } \\
\text { dwelling }\end{array}$ & $\begin{array}{l}\text { Quietness in \& around } \\
\text { dwelling }\end{array}$ & $\begin{array}{l}\text { Car parking } \\
\text { spaces }\end{array}$ \\
\hline YS & 0.16 & 0.24 & $\mathbf{0 . 3 6 ^ { * }}$ & 0.18 & 0.13 \\
YF & $\mathbf{0 . 3 6 ^ { * }}$ & $\mathbf{0 . 5 3 ^ { * * }}$ & 0.10 & 0.20 & 0.29 \\
OC & $\mathbf{0 . 4 6 ^ { * * }}$ & 0.21 & 0.24 & $\mathbf{0 . 3 2 *}$ & 0.16 \\
EN & 0.09 & $\mathbf{0 . 6 4 ^ { * * }}$ & 0.31 & 0.30 & 0.03 \\
\hline
\end{tabular}

"Correlation is significant at the 0.01 level

*Correlation is significant at the 0.05 level

'satisfaction with area of dwelling' and 'satisfaction with quietness in and around dwelling'. Finally, for EN, the best and only significant predictor was 'satisfaction with views from dwelling'.

\section{Predictors of neighborhood satisfaction}

Correlations between 'neighborhood satisfaction' and the different aspects of the neighborhood satisfaction investigated are indicated in Table 7. For YF and OC, satisfaction with the neighborhood was significantly and positively correlated with all the aspects of 'neighborhood satisfaction' investigated: 'satisfaction with neighborhood attractiveness', 'satisfaction with neighborhood cleanliness', 'satisfaction with neighborhood maintenance', 'satisfaction with green areas', 'satisfaction with play areas for children', and 'satisfaction with the possibility of walking around dwelling'. For YS, 'neighborhood satisfaction' was only found to be significantly and positively correlated with 'satisfaction with neighborhood attractiveness' and 'satisfaction with neighborhood maintenance'. As for EN, 'neighborhood satisfaction' was not found to be statistically correlated with any of the aspects investigated.

For each of the four life cycle stages, MLRA was conducted to identify the best significant predictors of 'neighborhood satisfaction' among the different aspects investigated. As shown in Table 8, for YF, the significant predictors were 'satisfaction with neighborhood attractiveness', 'satisfaction with neighborhood maintenance', and 'satisfaction with the possibility of walking around dwelling'. For OC, they were 'satisfaction with neighborhood attractiveness' and 'satisfaction with neighborhood maintenance'. As for YS and EN, MLRA results did not reveal any significant predictors.

Table 6 Regression analysis results for dwelling unit satisfaction

\begin{tabular}{|c|c|c|c|c|c|c|c|c|c|c|}
\hline \multirow{3}{*}{ Life cycle stages } & \multicolumn{10}{|c|}{ Aspects of dwelling unit satisfaction } \\
\hline & \multicolumn{2}{|c|}{$\begin{array}{l}\text { Area of } \\
\text { dwelling }\end{array}$} & \multicolumn{2}{|c|}{$\begin{array}{l}\text { Views from } \\
\text { dwelling }\end{array}$} & \multicolumn{2}{|c|}{$\begin{array}{l}\text { Privacy in } \\
\text { dwelling }\end{array}$} & \multicolumn{2}{|c|}{$\begin{array}{l}\text { Quietness in and } \\
\text { around dwelling }\end{array}$} & \multicolumn{2}{|c|}{$\begin{array}{l}\text { Car parking } \\
\text { spaces }\end{array}$} \\
\hline & $R^{2}$ & Beta & $R^{2}$ & Beta & $R^{2}$ & Beta & $R^{2}$ & Beta & $R^{2}$ & Beta \\
\hline YS & 0.22 & 0.23 & 0.22 & 0.12 & $0.22 *$ & 0.66 & 0.22 & 0.39 & 0.22 & 0.08 \\
\hline YF & $0.42^{*}$ & 0.33 & $0.42^{* *}$ & 0.51 & 0.42 & 0.29 & 0.42 & 0.08 & 0.42 & 0.17 \\
\hline OC & $0.38^{*}$ & 0.53 & 0.38 & 0.18 & 0.38 & 0.16 & $0.38^{*}$ & 0.52 & 0.38 & 0.16 \\
\hline EN & 0.48 & 0.11 & $0.48^{* *}$ & 0.66 & 0.48 & 0.08 & 0.48 & 0.26 & 0.48 & 0.98 \\
\hline
\end{tabular}

**Regression is significant at the 0.01 level

* Regression is significant at the 0.05 level 
Table 7 Correlations between neighborhood satisfaction and its different aspects

\begin{tabular}{|c|c|c|c|c|c|c|}
\hline \multirow[b]{2}{*}{$\begin{array}{l}\text { Life cycle } \\
\text { stages }\end{array}$} & \multicolumn{6}{|c|}{ Aspects of neighborhood satisfaction } \\
\hline & Attractiveness & Cleanliness & Maintenance & $\begin{array}{l}\text { Green } \\
\text { areas }\end{array}$ & $\begin{array}{l}\text { Play areas for } \\
\text { children }\end{array}$ & $\begin{array}{l}\text { Possibility of walking } \\
\text { around dwelling }\end{array}$ \\
\hline$\overline{Y S}$ & $0.35^{*}$ & 0.25 & $0.38^{*}$ & 0.23 & 0.06 & 0.04 \\
\hline YF & $0.69^{* *}$ & $0.50^{* *}$ & $0.65^{* *}$ & $0.44^{* *}$ & $0.42^{* *}$ & $0.65^{* *}$ \\
\hline OC & $0.54^{* *}$ & $0.43^{*}$ & $0.53^{* *}$ & $0.41 *$ & $0.33^{*}$ & $0.51^{* *}$ \\
\hline EN $\quad 0.00$ & & 0.32 & 0.40 & 0.16 & 0.00 & 0.28 \\
\hline
\end{tabular}

**Correlation is significant at the 0.01 level

${ }^{*}$ Correlation is significant at the 0.05 level

\section{Predictors of sense of security}

Correlations between 'sense of security' and its different investigated aspects are indicated in Table 9. The table shows that 'sense of security' was found to be significantly positively correlated with 'safety from house burglary', 'presence of security at the main gates' and 'safety of children playing around dwelling' for YS; 'safety of walking alone around dwelling', 'safety of children playing around dwelling', 'safety from traffic accidents' and 'presence of security at the main gates' for YF and OC; 'safety from house burglary', 'safety from traffic accidents', and 'presence of security at the main gates' for EN.

MLRA was conducted to identify, for each of the four life cycle stages, the best predictors of 'sense of security' among the different aspects investigated. As shown in Table 10, for YS, the significant predictors were 'safety from house burglary', 'safety from traffic accidents' and 'presence of security at the main gates'. For YF, the only significant predictor was 'safety of children playing around dwelling'. For OC, the two significant predictors were 'safety from traffic accidents' and 'presence of security at the main gates'. And for EN, the only significant predictor of 'sense of security' was 'safety from house burglary'.

\section{Predictors of satisfaction with mobility and access to services}

Correlations between 'satisfaction with mobility and access to services' and its different aspects are shown in Table 11. It was found that for YS, 'satisfaction with mobility and access to services' was significantly positively correlated with 'satisfaction with access to public transportation/ taxis/ uber', 'ease of going to work/school', 'ease of buying daily

Table 8 Regression analysis results for neighborhood satisfaction

\begin{tabular}{|c|c|c|c|c|c|c|c|c|c|c|c|c|}
\hline \multirow{3}{*}{ Life cycle stages } & \multicolumn{12}{|c|}{ Aspects of neighborhood satisfaction } \\
\hline & \multicolumn{2}{|c|}{ Attractiveness } & \multicolumn{2}{|c|}{ Cleanliness } & \multicolumn{2}{|c|}{ Maintenance } & \multicolumn{2}{|c|}{$\begin{array}{l}\text { Green } \\
\text { areas }\end{array}$} & \multicolumn{2}{|c|}{$\begin{array}{l}\text { Play areas } \\
\text { for children }\end{array}$} & \multicolumn{2}{|c|}{$\begin{array}{l}\text { Possibility of } \\
\text { walking around } \\
\text { dwelling }\end{array}$} \\
\hline & $R^{2}$ & Beta & $R^{2}$ & Beta & $R^{2}$ & Beta & $R^{2}$ & Beta & $R^{2}$ & Beta & $R^{2}$ & Beta \\
\hline YS & 0.21 & 0.29 & 0.21 & 0.04 & 0.21 & 0.36 & 0.21 & 0.11 & 0.21 & 0.08 & 0.21 & 0.17 \\
\hline YF & $0.68^{* * *}$ & 0.59 & 0.68 & 0.28 & $0.68^{*}$ & 0.34 & 0.68 & 0.15 & 0.68 & 0.02 & $0.68^{* *}$ & 0.41 \\
\hline OC & $0.51^{*}$ & 0.39 & 0.51 & 0.21 & $0.51^{*}$ & 0.40 & 0.51 & 0.42 & 0.51 & 0.02 & 0.51 & 0.32 \\
\hline EN & 0.36 & 0.18 & 0.36 & 0.41 & 0.36 & 0.40 & 0.36 & 0.01 & 0.36 & 0.22 & 0.36 & 0.19 \\
\hline
\end{tabular}

***Regression is significant at the 0.001 level

**Regression is significant at the 0.01 level

${ }^{*}$ Regression is significant at the 0.05 level 
Table 9 Correlations between sense of security and its different aspects

\begin{tabular}{llllll}
\hline Aspects of sense of security & & \\
\hline $\begin{array}{l}\text { Life } \\
\text { cycle } \\
\text { stages }\end{array}$ & $\begin{array}{l}\text { Safety from } \\
\text { house } \\
\text { burglary }\end{array}$ & $\begin{array}{l}\text { Walking alone } \\
\text { around dwelling }\end{array}$ & $\begin{array}{l}\text { Playing of children } \\
\text { around dwelling }\end{array}$ & $\begin{array}{l}\text { Safety from } \\
\text { traffic } \\
\text { accidents }\end{array}$ & $\begin{array}{l}\text { Presence of security } \\
\text { at the main gates }\end{array}$ \\
\hline YS & $\mathbf{0 . 7 8 ^ { * * }}$ & 0.23 & $\mathbf{0 . 5 1 ^ { * * }}$ & 0.20 & $\mathbf{0 . 5 4 ^ { * * }}$ \\
YF & 0.26 & $\mathbf{0 . 4 2 ^ { * * }}$ & $\mathbf{0 . 7 0 ^ { * * }}$ & $\mathbf{0 . 5 1}$ & $\mathbf{0 . 3 1 ^ { * * }}$ \\
OC & 0.25 & $\mathbf{0 . 4 8 ^ { * * }}$ & $\mathbf{0 . 4 1 ^ { * }}$ & $\mathbf{0 . 6 9 ^ { * * }}$ & $\mathbf{0 . 6 3 ^ { * * }}$ \\
EN & $\mathbf{0 . 6 4 ^ { * * }}$ & 0.24 & 0.41 & $\mathbf{0 . 5 1 ^ { * }}$ & $\mathbf{0 . 4 4 ^ { * }}$ \\
\hline
\end{tabular}

**Correlation is significant at the 0.01 level

*Correlation is significant at the 0.05 level

needs', 'ease of going to the club' and 'ease of going to recreational places'. For EN, it was only found to be significantly positively correlated with 'ease of buying daily needs'. As for YF and OC, 'satisfaction with mobility and access to services' was significantly correlated with all of the aspects investigated.

MLRA identified the best predictors of 'satisfaction with mobility and access to services' among the different aspects investigated for each of the four life cycle stages. As shown in Table 12, for YS, the significant predictors were: 'satisfaction with access to public transportation/ taxis/ uber' and 'ease of going to the club'. For YF, the only significant predictor was 'ease of going to work/ school'. For OC, the only significant predictor was 'ease of going to the club'. Finally, for EN, the only significant predictor was 'ease of buying daily needs'.

\section{Predictors of satisfaction with the social environment}

Correlations between 'satisfaction with the social environment' and its different aspects are shown in Table 13. For YS, 'satisfaction with the social environment' was positively significantly correlated with all of the aspects investigated. For YF, it was significantly correlated with 'satisfaction with ease of meeting family and friends living outside of Al-Rehab', 'sense of belonging to Al-Rehab', 'satisfaction with social interaction among residents', 'satisfaction with cooperation and support between Al-Rehab residents', and 'participation of residents in management and decision making'. For OC, it was significantly correlated with 'social compatibility', 'sense of community', 'sense of belonging

Table 10 Regression analysis results for sense of security

\begin{tabular}{|c|c|c|c|c|c|c|c|c|c|c|}
\hline \multirow{3}{*}{ Life cycle stages } & \multicolumn{10}{|c|}{ Aspects of sense of security } \\
\hline & \multicolumn{2}{|c|}{$\begin{array}{l}\text { Safety from } \\
\text { house } \\
\text { burglary }\end{array}$} & \multicolumn{2}{|c|}{$\begin{array}{l}\text { Walking } \\
\text { alone } \\
\text { around } \\
\text { dwelling }\end{array}$} & \multicolumn{2}{|c|}{$\begin{array}{l}\text { Playing of } \\
\text { children } \\
\text { around } \\
\text { dwelling }\end{array}$} & \multirow{2}{*}{$\begin{array}{l}\text { Safety from traffic accidents } \\
R^{2}\end{array}$} & \multicolumn{3}{|c|}{$\begin{array}{l}\text { Presence of } \\
\text { security at the } \\
\text { main gates }\end{array}$} \\
\hline & $R^{2}$ & Beta & $R^{2}$ & Beta & $R^{2}$ & Beta & & Beta & $R^{2}$ & Beta \\
\hline YS & $0.71 * * *$ & 0.72 & 0.71 & 0.03 & 0.71 & 0.08 & $0.71 *$ & 0.33 & $0.71 *$ & 0.34 \\
\hline YF & 0.50 & 0.1 & 0.50 & 0.11 & $0.50^{* * *}$ & 0.67 & 0.50 & 0.01 & 0.50 & 0.06 \\
\hline OC & 0.61 & 0.17 & 0.61 & 0.18 & 0.61 & 0.01 & $0.61^{*}$ & 0.38 & $0.61 *$ & 0.35 \\
\hline EN & $0.67^{* *}$ & 0.59 & 0.67 & 0.16 & 0.67 & 0.11 & 0.67 & 0.31 & 0.67 & 0.29 \\
\hline
\end{tabular}

***Regression is significant at the 0.001 level

**Regression is significant at the 0.01 level

${ }^{*}$ Regression is significant at the 0.05 level 
Table 11 Correlations between satisfaction with mobility and access to services and its different aspects

\begin{tabular}{|c|c|c|c|c|c|c|c|}
\hline \multirow[b]{2}{*}{$\begin{array}{l}\text { Life } \\
\text { cycle } \\
\text { stages }\end{array}$} & \multicolumn{6}{|c|}{ Aspects of satisfaction with mobility and access to services } & \multirow[b]{2}{*}{$\begin{array}{l}\text { Going to } \\
\text { recreational } \\
\text { places }\end{array}$} \\
\hline & $\begin{array}{l}\text { Going in } \\
\text { and out of } \\
\text { Al-Rehab }\end{array}$ & $\begin{array}{l}\text { Access to public } \\
\text { transportation/ } \\
\text { taxis/uber }\end{array}$ & $\begin{array}{l}\text { Going to } \\
\text { work/ } \\
\text { school }\end{array}$ & $\begin{array}{l}\text { Buying } \\
\text { daily } \\
\text { needs }\end{array}$ & $\begin{array}{l}\text { Access to } \\
\text { health-care } \\
\text { services }\end{array}$ & $\begin{array}{l}\text { Going to } \\
\text { the club of } \\
\text { Al-Rehab }\end{array}$ & \\
\hline YS & 0.24 & $0.73^{* *}$ & $0.51^{* *}$ & $0.37^{*}$ & 0.18 & $0.60^{* *}$ & $0.47^{* *}$ \\
\hline YF & $0.57^{* *}$ & $0.51^{* *}$ & $0.72^{* *}$ & $0.56^{* *}$ & $0.65^{* *}$ & $0.44^{* *}$ & $0.53^{* *}$ \\
\hline OC & $0.46^{* *}$ & $0.54 * *$ & $0.57^{* *}$ & $0.57^{* *}$ & $0.37^{*}$ & $0.57^{* *}$ & $0.42^{*}$ \\
\hline EN & 0.17 & 0.18 & 0.40 & $0.74^{* *}$ & 0.12 & 0.36 & 0.19 \\
\hline
\end{tabular}

**Correlation is significant at the 0.01 level

*Correlation is significant at the 0.05 level

to Al-Rehab', 'satisfaction with social interaction among residents', and 'satisfaction with cooperation and support between Al-Rehab residents'. For EN, 'satisfaction with the social environment' was only significantly correlated with 'satisfaction with ease of meeting family and friends living outside of Al-Rehab'.

MLRA identified, for each of the four life cycle stages, the best predictors of 'satisfaction with the social environment'. As shown in Table 14, for YS and EN, the only significant predictor was 'satisfaction with ease of meeting family and friends living outside of Al-Rehab'. For YF, the two significant predictors were 'sense of community' and 'sense of belonging to Al-Rehab'. For OC, MLRA results did not show any significant predictor.

\section{Predictors of overall residential satisfaction}

Correlations between 'overall residential satisfaction' (satisfaction with life in a GC) and components of residential satisfaction are indicated in Table 15. For respondents as a whole, 'overall residential satisfaction' was found to be significantly positively correlated with all of the components of residential satisfaction. However, for the different life cycle groups, 'overall residential satisfaction' was not significantly correlated with all of the components and correlated components tended to differ from one group to another. These results seem to confirm that needs and aspirations for living in a GC vary according to stages in the life cycle. As shown in the table, for YS, 'overall residential

Table 12 Regression analysis results of satisfaction with mobility and access to services

\begin{tabular}{|c|c|c|c|c|c|c|c|c|c|c|c|c|c|}
\hline \multirow{3}{*}{$\begin{array}{l}\text { Life cycle } \\
\text { stages }\end{array}$} & \multicolumn{13}{|c|}{ Aspects of satisfaction with mobility and access to services } \\
\hline & \multicolumn{2}{|c|}{$\begin{array}{l}\text { Going in } \\
\text { and out of } \\
\text { Al-Rehab }\end{array}$} & \multicolumn{2}{|c|}{$\begin{array}{l}\text { Access to } \\
\text { public } \\
\text { transportation/ } \\
\text { taxis/ uber }\end{array}$} & \multicolumn{2}{|c|}{$\begin{array}{l}\text { Going to } \\
\text { work/ } \\
\text { school }\end{array}$} & \multicolumn{2}{|c|}{$\begin{array}{l}\text { Buying } \\
\text { daily } \\
\text { needs }\end{array}$} & \multicolumn{2}{|c|}{$\begin{array}{l}\text { Access to } \\
\text { health- } \\
\text { care } \\
\text { services }\end{array}$} & \multicolumn{2}{|c|}{$\begin{array}{l}\text { Going to } \\
\text { the club of } \\
\text { Al-Rehab }\end{array}$} & \multirow{2}{*}{$\begin{array}{l}\text { Going to } \\
\text { recreational } \\
\text { places } \\
R^{2} \\
\text { Beta }\end{array}$} \\
\hline & $R^{2}$ & Beta & $R^{2}$ & Beta & $R^{2}$ & Beta & $R^{2}$ & Beta & $R^{2}$ & Beta & $R^{2}$ & Beta & \\
\hline YS & 0.63 & 0.02 & $0.63^{* * *}$ & 0.66 & 0.63 & 0.15 & 0.63 & 0.09 & 0.63 & 0.16 & $0.63^{* *}$ & 0.48 & 0.630 .13 \\
\hline YF & 0.58 & 0.27 & 0.58 & 0.07 & $0.58^{*}$ & 0.48 & 0.58 & 0.16 & 0.58 & 0.39 & 0.58 & 0.12 & 0.580 .01 \\
\hline OC & 0.56 & 0.074 & 0.56 & 0.18 & 0.56 & 0.16 & 0.56 & 0.36 & 0.56 & 0.39 & $0.56^{*}$ & 0.47 & 0.560 .18 \\
\hline EN & 0.62 & 0.29 & 0.62 & 0.05 & 0.62 & 0.04 & $\begin{array}{l}0.62^{\prime} \\
0.77\end{array}$ & & 0.62 & 0.14 & 0.62 & 0.11 & 0.620 .10 \\
\hline
\end{tabular}

\footnotetext{
***Regression is significant at the 0.001 level

**Regression is significant at the 0.01 level

* Regression is significant at the 0.05 level
} 
Table 13 Correlations between satisfaction with the social environment and its different aspects

\begin{tabular}{|c|c|c|c|c|c|c|c|}
\hline \multirow{2}{*}{$\begin{array}{l}\text { Life } \\
\text { cycle } \\
\text { stages }\end{array}$} & \multicolumn{7}{|c|}{ Aspects of satisfaction with the social environment } \\
\hline & $\begin{array}{l}\text { Meeting } \\
\text { family and } \\
\text { friends }\end{array}$ & $\begin{array}{l}\text { Social } \\
\text { compatibility }\end{array}$ & $\begin{array}{l}\text { Sense of } \\
\text { community }\end{array}$ & $\begin{array}{l}\text { Sense of } \\
\text { belonging }\end{array}$ & $\begin{array}{l}\text { Social } \\
\text { interaction }\end{array}$ & $\begin{array}{l}\text { Cooperation } \\
\text { and support }\end{array}$ & $\begin{array}{l}\text { Participation } \\
\text { in } \\
\text { management }\end{array}$ \\
\hline YS & $0.40^{*}$ & $0.41^{*}$ & $0.49 * *$ & $0.36^{*}$ & $0.55^{* *}$ & $0.46^{* *}$ & $0.41 *$ \\
\hline YF & $0.45^{* *}$ & 0.23 & 0.14 & $0.49 * *$ & $0.47^{* *}$ & $0.31 *$ & $0.42^{* *}$ \\
\hline OC & 0.32 & $0.57^{* *}$ & $0.38^{*}$ & $0.51 * *$ & $0.49 * *$ & $0.52^{* *}$ & 0.21 \\
\hline EN & $0.41 *$ & 0.03 & 0.17 & 0.15 & 0.18 & 0.24 & 0.25 \\
\hline
\end{tabular}

**Correlation is significant at the 0.01 level

*Correlation is significant at the 0.05 level

satisfaction' was only significantly correlated with 'neighborhood satisfaction'. For YF, it was significantly correlated with 'neighborhood satisfaction', 'sense of security', and 'satisfaction with the social environment'. For OC, it was only significantly correlated with 'satisfaction with the social environment'. Finally, for EN, 'overall residential satisfaction' was only significantly correlated with 'satisfaction with dwelling unit'.

MLRA was conducted to identify the best predictors of 'overall residential satisfaction' among the different components of overall residential satisfaction. As shown in Table 16, for respondents as a whole, the two significant predictors were 'sense of security' and 'satisfaction with the social environment'. However, for both YF and OC, the only significant predictor was 'satisfaction with the social environment'. For EN, the only significant predictor was 'satisfaction with dwelling unit'. As for YS, MLRA did not reveal any significant predictor.

\section{Discussion}

Results suggest that residents of Al-Rehab GC have relatively high levels of overall residential satisfaction. Results also show high levels of satisfaction for the different components of residential satisfaction: (1) dwelling satisfaction, (2) neighborhood satisfaction, (3) sense of security, (4) satisfaction with mobility and access to services, and (5) satisfaction with the social environment. ANOVA results did not yield any significant differences between mean ratings of the different life cycle groups both for overall residential satisfaction and for its various components. However, MLRA results indicated very clear differences between stages in the life cycle in terms of the most important

Table 14 Regression analysis results for satisfaction with the social environment

\begin{tabular}{|c|c|c|c|c|c|c|c|c|c|c|c|c|c|c|}
\hline \multirow{3}{*}{$\begin{array}{l}\text { Life } \\
\text { cycle } \\
\text { stages }\end{array}$} & \multicolumn{14}{|c|}{ Aspects of satisfaction with the social environment } \\
\hline & \multicolumn{2}{|c|}{$\begin{array}{l}\text { Meeting } \\
\text { family and } \\
\text { friends }\end{array}$} & \multicolumn{2}{|c|}{$\begin{array}{l}\text { Social } \\
\text { compatibility }\end{array}$} & \multicolumn{2}{|c|}{$\begin{array}{l}\text { Sense of } \\
\text { community }\end{array}$} & \multicolumn{2}{|c|}{$\begin{array}{l}\text { Sense of } \\
\text { belonging }\end{array}$} & \multicolumn{2}{|c|}{$\begin{array}{l}\text { Social } \\
\text { interaction }\end{array}$} & \multirow{2}{*}{$\begin{array}{l}\text { Cooperation } \\
\text { and support } \\
R^{2}\end{array}$} & \multicolumn{3}{|c|}{$\begin{array}{l}\text { Participation in } \\
\text { management }\end{array}$} \\
\hline & $R^{2}$ & Beta & $R^{2}$ & Beta & $R^{2}$ & Beta & $R^{2}$ & Beta & $R^{2}$ & Beta & & Beta & $R^{2}$ & Beta \\
\hline YS & $0.50^{*}$ & 0.30 & 0.50 & 0.09 & 0.50 & 0.30 & 0.50 & 0.11 & 0.50 & 0.29 & 0.50 & 0.26 & 0.50 & 0.27 \\
\hline YF & 0.46 & 0.24 & 0.46 & 0.15 & $0.46^{*}$ & 0.51 & $0.46^{*}$ & 0.38 & 0.46 & 0.47 & 0.46 & 0.19 & 0.46 & 0.11 \\
\hline OC & 0.41 & 0.15 & 0.41 & 0.39 & 0.41 & 0.35 & 0.41 & 0.26 & 0.41 & 0.02 & 0.41 & 0.26 & 0.41 & 0.09 \\
\hline EN & $0.49^{*}$ & 0.64 & 0.49 & 0.22 & 0.49 & 0.01 & 0.49 & 0.03 & 0.49 & 0.24 & 0.49 & 0.22 & 0.49 & 0.46 \\
\hline
\end{tabular}

**Regression is significant at the 0.01 level

*Regression is significant at the 0.05 level 
Table 15 Correlations between 'overall residential satisfaction' and components of residential satisfaction

\begin{tabular}{|c|c|c|c|c|c|c|}
\hline \multicolumn{2}{|c|}{$\begin{array}{l}\text { Components } \\
\text { of residential } \\
\text { satisfaction }\end{array}$} & $\begin{array}{l}\text { Dwelling } \\
\text { satisfaction }\end{array}$ & $\begin{array}{l}\text { Neighborhood } \\
\text { satisfaction }\end{array}$ & $\begin{array}{l}\text { Sense of } \\
\text { security }\end{array}$ & $\begin{array}{l}\text { Mobility and } \\
\text { access to services }\end{array}$ & $\begin{array}{l}\text { Satisfaction with the } \\
\text { social environment }\end{array}$ \\
\hline \multicolumn{2}{|c|}{$\begin{array}{l}\text { All } \\
\text { respondents }\end{array}$} & $0.21^{*}$ & $0.25^{*}$ & $0.34^{* *}$ & $0.23^{* *}$ & $0.37^{* *}$ \\
\hline \multirow{4}{*}{$\begin{array}{l}\text { Life cycle } \\
\text { stages }\end{array}$} & YS & 0.32 & $0.36^{*}$ & 0.28 & 0.20 & 0.18 \\
\hline & YF & 0.29 & $0.41^{* *}$ & $0.50^{* *}$ & 0.19 & $0.52^{* *}$ \\
\hline & $\mathrm{OC}$ & 0.05 & 0.20 & 0.23 & 0.30 & $0.47^{* *}$ \\
\hline & EN & $0.61^{* *}$ & 0.17 & 0.38 & 0.39 & 0.34 \\
\hline
\end{tabular}

**Correlation is significant at the 0.01 level

${ }^{*}$ Correlation is significant at the 0.05 level

predictors of overall residential satisfaction and the most important predictors of the different components of residential satisfaction (see Tables 17 and 18).

For YF and OC, generally households with younger or older children, the social environment within the GC appeared to be very important. For both of these groups, satisfaction with the social environment was found to be the only significant predictor of overall residential satisfaction. Furthermore, particularly for YF; sense of community and sense of belonging to Al-Rehab were the most important predictors of satisfaction with the social environment.

Also, for both YF and OC, in contrast with other life cycle groups, satisfaction with the area of dwelling was found to be one of the most important predictors of dwelling satisfaction. The importance of the area of dwelling unit for these two particular groups could be related to the presence of children within the household. However, it could also be related to a concern with the social image or social identity projected by the residential environment, including both the dwelling unit and the neighborhood. In fact, for YF and OC, satisfaction with the attractiveness and maintenance of the neighborhood were found to be among the most important predictors of neighborhood satisfaction.

In addition, results revealed that for both YF and OC, residential satisfaction was strongly related to the needs of their children and to concerns about their safety. For example, for YF, the perception of safety of children playing in areas around the dwelling was found to be the most important predictor of sense of security in the residential

Table 16 Regression analysis results for 'overall residential satisfaction'

\begin{tabular}{|c|c|c|c|c|c|c|c|c|c|c|c|}
\hline \multirow[t]{2}{*}{$\begin{array}{l}\text { Components of } \\
\text { residential } \\
\text { satisfaction }\end{array}$} & & \multicolumn{2}{|c|}{$\begin{array}{l}\text { Dwelling } \\
\text { satisfaction }\end{array}$} & \multirow{2}{*}{$\begin{array}{l}\text { Neighborhood } \\
\text { satisfaction }\end{array}$} & \multicolumn{2}{|c|}{$\begin{array}{l}\text { Sense of } \\
\text { security }\end{array}$} & \multicolumn{3}{|c|}{$\begin{array}{l}\text { Mobility and } \\
\text { access to } \\
\text { services }\end{array}$} & \multicolumn{2}{|c|}{$\begin{array}{l}\text { Satisfaction } \\
\text { with the } \\
\text { social } \\
\text { environment }\end{array}$} \\
\hline & & $R^{2}$ & Beta & & Beta & $R^{2}$ & Beta & $R^{2}$ & Beta & $R^{2}$ & Beta \\
\hline All respondents & & 0.20 & 0.03 & 0.20 & 0.02 & $0.20^{*}$ & 0.23 & 0.20 & 0.05 & $0.20^{* *}$ & 0.30 \\
\hline \multirow{4}{*}{$\begin{array}{l}\text { Life cycle } \\
\text { stages }\end{array}$} & YS & 0.14 & 0.29 & 0.14 & 0.09 & 0.14 & 0.20 & 0.14 & 0.01 & 0.14 & 0.02 \\
\hline & YF & 0.40 & 0.03 & 0.40 & 0.12 & 0.40 & 0.29 & 0.40 & 0.03 & $0.40^{*}$ & 0.34 \\
\hline & OC & 0.30 & 0.24 & 0.30 & 0.01 & 0.30 & 0.01 & 0.30 & 0.22 & $0.30^{*}$ & 0.46 \\
\hline & EN & $0.57^{*}$ & 0.51 & 0.57 & 0.42 & 0.57 & 0.14 & 0.57 & 0.35 & 0.57 & 0.41 \\
\hline
\end{tabular}

**Regression is significant at the 0.01 level *Regression is significant at the 0.05 level 
Table 17 Most important predictors of overall residential satisfaction for the different life cycle stages

\begin{tabular}{|c|c|c|c|c|c|c|c|c|}
\hline \multirow[t]{2}{*}{$\begin{array}{l}\text { Components of overall } \\
\text { residential satisfaction }\end{array}$} & \multicolumn{4}{|c|}{$\begin{array}{l}\text { Significant correlations with } \\
\text { overall residential satisfaction }\end{array}$} & \multicolumn{4}{|c|}{$\begin{array}{l}\text { Significant predictors of } \\
\text { overall residential } \\
\text { satisfaction }\end{array}$} \\
\hline & YS & YF & OC & EN & YS & YF & OC & EN \\
\hline Dwelling satisfaction & & & & $\checkmark$ & & & & $\checkmark$ \\
\hline Neighborhood satisfaction & $\checkmark$ & $\checkmark$ & & & & & & \\
\hline Sense of security & & $\checkmark$ & & & & & & \\
\hline \multicolumn{9}{|l|}{ Mobility and access to services } \\
\hline Satisfaction with the social environment & & $\checkmark$ & $\checkmark$ & & & $\checkmark$ & $\checkmark$ & \\
\hline
\end{tabular}

environment. And, the ease of going to work or to children's school was found to be the most important predictor of satisfaction with mobility and access to services.

For OC, whose children are older and thus tend to have a greater range of independent mobility, safety from traffic accidents was the most important predictor of sense of security. And for them, the ease of going to the club was the most important predictor of satisfaction with mobility and access to services. In fact, for YS, whose age range corresponds to the ages of OC children, results were very similar. Indeed, for YS, safety from traffic accidents and the ease of going to the club were among the most important predictors of sense of security and satisfaction with mobility and access to services respectively.

Results for YS stress the importance of mobility in relation to residential satisfaction. For example, for YS, satisfaction with access to public transportation, taxis, and uber was another important predictor of satisfaction with mobility and access to services. Also, for YS, satisfaction with ease of meeting family or friends living outside the GC was the most important predictor of satisfaction with the social environment.

While for YF and OC residential satisfaction was particularly related to the social environment within the GC, for EN, residential satisfaction appeared to be much more related to the dwelling unit itself. Results indicated that, for EN, satisfaction with dwelling unit was the most important predictor of overall residential satisfaction. Also, for EN, perceived house burglary risk was found to be the most important aspect of sense of security in the residential environment.

For EN, the social environment within the GC appeared to be much less important than for YF and OC. First, for EN, satisfaction with the social environment was not found to be an important predictor of overall residential satisfaction. Furthermore, for EN, like for YS, the only significant predictor of satisfaction with the social environment was satisfaction with ease of meeting family or friends living outside the GC. Finally, for EN, the ease of buying daily needs appeared to be much more important than for the other groups. Indeed, in contrast with the other life cycle groups, the ease of buying daily needs was the most important predictor of satisfaction with mobility and access to services.

\section{Conclusions}

The housing literature emphasizes that residential satisfaction, as a multi-dimensional concept, is strongly related to stages in the life cycle; as needs and priorities related to 
Table 18 Most important predictors for the different components of overall residential satisfaction

\begin{tabular}{|c|c|c|c|c|c|c|c|c|}
\hline & \multicolumn{4}{|c|}{$\begin{array}{l}\text { Significant } \\
\text { correlations with }\end{array}$} & \multicolumn{4}{|c|}{$\begin{array}{l}\text { Significant } \\
\text { predictors of }\end{array}$} \\
\hline & YS & YF & OC & EN & YS & YF & OC & EN \\
\hline Aspects of dwelling satisfaction & \multicolumn{8}{|c|}{ Overall dwelling satisfaction } \\
\hline Area of dwelling & & $\checkmark$ & $\checkmark$ & & & $\checkmark$ & $\checkmark$ & \\
\hline Views from dwelling & & $\checkmark$ & & $\checkmark$ & & $\checkmark$ & & $\checkmark$ \\
\hline Privacy in dwelling & $\checkmark$ & & & & $\checkmark$ & & & \\
\hline Quietness in and around dwelling & & & $\checkmark$ & & & & $\checkmark$ & \\
\hline \multicolumn{9}{|l|}{ Car parking spaces } \\
\hline Aspects of neighborhood satisfaction & \multicolumn{8}{|c|}{ Overall neighborhood satisfaction } \\
\hline Attractiveness & $\checkmark$ & $\checkmark$ & $\checkmark$ & & & $\checkmark$ & $\checkmark$ & \\
\hline Cleanliness & & $\checkmark$ & $\checkmark$ & & & & & \\
\hline Maintenance & $\checkmark$ & $\checkmark$ & $\checkmark$ & & & $\checkmark$ & $\checkmark$ & \\
\hline Green areas & & $\checkmark$ & $\checkmark$ & & & & & \\
\hline Play areas for children & & $\checkmark$ & $\checkmark$ & & & & & \\
\hline Possibility of walking around dwelling & & $\checkmark$ & $\checkmark$ & & & $\checkmark$ & & \\
\hline Aspects of sense of security & \multicolumn{8}{|c|}{ Overall sense of security } \\
\hline Safety from house burglary & $\checkmark$ & & & $\checkmark$ & $\checkmark$ & & & $\checkmark$ \\
\hline Walking alone around dwelling & & $\checkmark$ & $\checkmark$ & & & & & \\
\hline Playing of children around dwelling & $\checkmark$ & $\checkmark$ & $\checkmark$ & & & $\checkmark$ & & \\
\hline Safety from traffic accidents & & $\checkmark$ & $\checkmark$ & $\checkmark$ & $\checkmark$ & & $\checkmark$ & \\
\hline Presence of security at the main gates & $\checkmark$ & $\checkmark$ & $\checkmark$ & $\checkmark$ & $\checkmark$ & & $\checkmark$ & \\
\hline
\end{tabular}

Aspects of satisfaction with mobility and access to services Overall satisfaction with mobility \& access to services

Going in and out of Al-Rehab

Access to public transportation/taxis/uber

Going to work/school

Buying daily needs

Access to health-care services

Going to the club of Al-Rehab

Going to recreational places

Aspects of satisfaction with the social environment

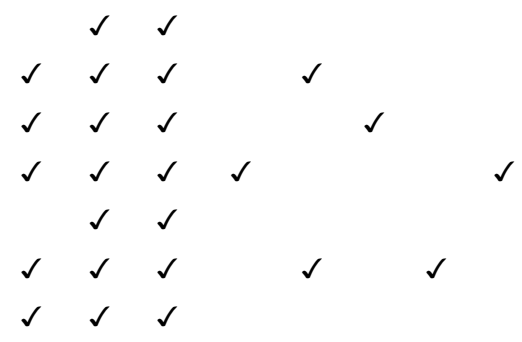

Meeting family and friends

Social compatibility

Sense of community

Sense of belonging

Social interaction

Cooperation and support

Overall satisfaction with the social environment

Participation in management

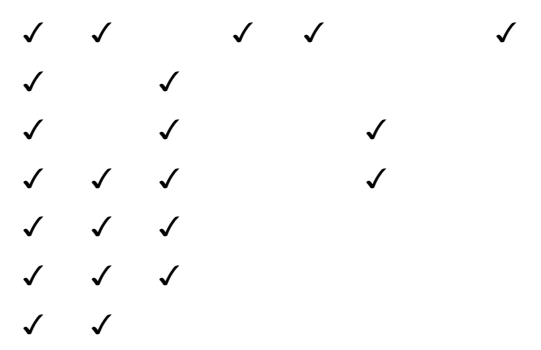

the residential environment tend to vary from one stage to another $[19,34,36,37,46$, 47]. Results of this study confirm this and suggest that it is also true in relation to GCs in the Egyptian context. The differences between stages in the life cycle in relation to residential satisfaction identified in this study can provide some guidance for the design of future GCs to better address the needs and priorities of diverse residents. 
The limitations of the study need to be pointed out to bring forth suggestions for future research. First because of the sampling method used and of the somewhat limited size of the sample, the generalization of the findings of the study must remain cautious. In particular the size of the sample may have contributed to the under-representation of less conventional household types in Egyptian society-such as persons yet to be married, divorced, or widowed living alone. Second, the study relied on a sample of residents of Al-Rehab GC. It should be stressed again that Al-Rehab cannot be considered to represent all GCs in Cairo. It is more representative of the large lifestyle GCs with relative self-sufficiency in terms of at least commercial and recreational facilities. Accordingly, there is not only a need for more research to confirm the findings of this study in relation to this particular type of GCs, but there is also a need for research to investigate other types of GCs in Cairo. It would also be interesting for future research to conduct similar studies in other countries to permit comparisons of similar GCs in other parts of the world. Methodologically, future studies could consider the use of indepth interviews to perhaps achieve a deeper and more complete understanding of residential satisfaction in GCs according to stages in the life cycle.

\section{Abbreviations}

GC: Gated community; YS: Young singles; YF: Heads of young family households; OC: Heads of households with older children; EN: Empty nesters

\section{Acknowledgements}

The authors would like to thank the reviewers for their suggestions that have enhanced the article.

\section{Authors' contributions}

YM conceptualized the research idea, methodology, participated in the interpretation of the results, reviewed the edited manuscript, and supervised the whole project. AF developed the computational technique and supervised the investigation and validation of the analytical work. FO performed the data collection process, data analysis, took part in the interpretation of the results, and updated the manuscript draft. All authors contributed to the discussion of the results and visualization of the final manuscript. All authors have read and approved the manuscript.

\section{Funding}

No specific funding has to be declared for this work.

\section{Availability of data and materials}

The data that support the findings of the current study and analyzed during the study are available from the corresponding author upon reasonable request.

\section{Declarations}

\section{Ethics approval and consent to participate}

Participation of the questionnaire respondents in this study was totally on a voluntary basis. Participants were clearly informed of the objectives of the study before consenting to fill out the questionnaire. All participants were above 16 years old. For participants under 20 years old, a consent to participate was obtained from their parents or legal guardians and they filled the questionnaire under their complete supervision. The article does not identify participants in any way and does not contain any of their personal information. Participants' answers to the questionnaire are only presented in statistical form.

Competing interests

The authors declare that they have no competing interests.

\section{Author details}

${ }^{1}$ Department of Architecture and Environmental Design, College of Engineering, Arab Academy for Science, Technology \& Maritime Transport, El-Moshir Ahmed Ismail St. off Salah Salem St, PO Box 2033, Cairo, Egypt. ${ }^{2}$ Department of Architecture and Environmental Design, College of Engineering, Arab Academy for Science, Technology \& Maritime Transport, Cairo, Egypt. ${ }^{3}$ Department of Architecture and Environmental Design, College of Engineering, Arab Academy for Science, Technology \& Maritime Transport, Cairo, Egypt. 
Received: 29 July 2021 Accepted: 6 November 2021

Published online: 07 December 2021

\section{References}

1. Grant $J$, Mittelsteadt $L$ (2004) Types of gated communities. Environ Plan B: Plan Des 31(6):913-930. https://doi.org/10.1 068/b3165

2. Mahgoub Y, Khalfani F (2012) Sustainability of gated communities in developing countries. Dev Country Stud 2(6):53-63

3. Aboubakr DA, Nasreldin Rl, Abdelfattah DA (2020) Assessing livability of public spaces in gated and ungated communities using the star model. J Eng Appl Sci 67(3):605-624

4. Blakely EJ, Snyder MG (1997) Fortress America: gated communities in the United States. Brookings Institution Press, Washington, D.C

5. Ilesanmi A (2012) The roots and fruits of gated communities in Lagos, Nigeria: social sustainability or segregation. In: Sustainable Futures Conference: Architecture/Urbanism in the Global South. Kampala, Uganda

6. Nassar U, Fathy A, Saleh A (2013) Urban Sustainability and connectivity in gated communities in Cairo, Egypt. In: Contemporary Urban Issues Conference (CUI'13) - DAKAM, At Istanbul, Turkey, Istanbul. Dakam

7. Bekleyen A, Yilmaz-Ay I (2016) Are gated communities indispensable for residents. Urbani izziv 27(1):149-161. https:// doi.org/10.5379/urbani-izziv-en-2016-27-01-005

8. El Sayed E (2016) Residents' satisfaction at gated communities in Egypt case study: new Cairo city in Greater Cairo Region (GCR). Int J Sci Eng Res 7(4):1185-1196

9. Tan TH (2016) Residential satisfaction in gated communities: case study of Desa Park City, Kuala Lumpur Malaysia. Prop Manag 34(2):84-99. https://doi.org/10.1108/PM-02-2015-0009

10. Salah N, Ayad H (2018) Why people choose gated communities: a case study of Alexandria metropolitan area. Alex Eng J 57(4):2743-2753. https://doi.org/10.1016/j.aej.2017.10.008

11. Yönet NA, Yirmibeşoğlu F (2018) Why People Prefer to Live in Gated Communities in Istanbul. Curr Urban Stud 6(1): 180-195. https://doi.org/10.4236/cus.2018.61010

12. Abdul Malek N, Ibrahim M (2008) Gated community, theory and implementation in landscape and housing area of Malaysia, Research Centre. International Islamic University, Malaysia

13. Jacob P, Chander S (2020) A qualitative analysis of residential satisfaction in gated communities - a case study of it Corridor, Chennai. Int J Adv Res Eng Technol 11(3):216-223

14. Atkinson R, Flint J (2004) Fortress UK? Gated communities, the spatial revolt of the elites and time-space trajectories of segregation. Hous Stud 19(6):875-892

15. Berköz L (2008) Gated communities: user satisfaction in housing environment in Istanbul. In: Building Comfortable and Liveable Environments for All- Universal Design At The Urban Scale, Atlanta. Georgia Tech University

16. Elhadary Y, Ali S (2017) A new trend in urban housing: gated communities in Khartoum, Sudan. Am J Sociol Res 7(1):4555

17. Jansen SJT (2012) The impact of socio-demographic characteristics, objective housing quality and preference on residential satisfaction. Delft University of Technology, OTB Research Institute for the Built Environment, Delft, The Netherlands

18. Borgoni R, Michelangeli A, Pirola F (2018) Residential satisfaction for a continuum of households: evidence from European countries. SSRN Electron J 378:1-30

19. Galster GC, Hesser GW (1981) Residential satisfaction. Environ Behav 13(6):735-758. https://doi.org/10.1177/001391 6581136006

20. Balestra C \& Sultan J, Home sweet home: the determinants of residential satisfaction and its relation with well-being, OECD Statistics Working Papers, OECD Publishing, Paris, 5, 54, 1-42, 2013

21. Waziri AG, Yusof NA, Abd Rahim NMS (2014) Occupants housing satisfaction: does age really matter. Urban Plan Transp Res Open Access J 2(1):341-353. https://doi.org/10.1080/21650020.2014.935467

22. Nasreldin TI (2016) The Future Of The Existing Gated Communities In Greater Cairo After January 2011. Faculty of Engineering, Cairo University, Cairo, Egypt

23. Mahmoud R, Rashed R (2016) New Cairo's urban paradox: all inclusive urbanism vs. social exclusion. SBE 16-Cairo, Cairo

24. Roitman S (2010) Gated communities: definitions, causes and consequences. Urban Des Plan 163(1):31-38. https://doi. org/10.1680/udap.2010.163.1.31

25. Manzelat R (2016) Gated communities and sense of community: a review on the social features of gated communities. Int J Civil Environ Struct Constr Archit Eng 10(5):671-676

26. Mohd T, Johari N, Abdul Ghani R (2016) Satisfaction level of gated and guarded community residents (case study: Meru Hills, Ipoh). Procedia Soc Behav Sci 222:747-754. https://doi.org/10.1016/j.sbspro.2016.05.144

27. Glasze G, Alkhayyal A (2002) Gated housing estates in the Arab world: case studies in Lebanon and Riyadh, Saudi Arabia. Environ Plan B: Plan Des 29(3):321-336. https://doi.org/10.1068/b12825t

28. Mokhtar N (2017) Between Accumulation and (In)Security: The Real Estate Industry and the Housing Crisis in Egypt. Master's thesis, the American University in Cairo. AUC Knowledge Fountain, Cairo

29. Kooshali AD, Parvizi R, Azeri ARK, Hosseini SB (2015) The Role of Nature (Green Space) in Parallel with Promotion of Relaxation and Satisfaction of Residents of Residential Complexes. Procedia Soc Behav Sci 202:361-372. https://doi.org/1 0.1016/j.sbspro.2015.08.240

30. Molloy R, Healy S, Mooney R (2018) Drivers of residential satisfaction and aspirations in Ireland. In: Working Paper, in European Network of Housing Researchers Annual (ENHR) Conference, Dublin, Ireland. The Housing Agency

31. Muiga J, Rukwaro R (2017) Drivers of gated community developments in urban areas (Case Study: Nairobi, Kenya). Int J Archit Urban Dev 7(4):5-18

32. Muiga J, Rukwaro R (2016) Satisfaction of residents with gated community lifestyle: the case of Nairobi County; Kenia. BEST: Int J Hum Arts Med Sci 4(12):85-104

33. Fernández GFM, Pérez FR, Abuínn JMR (2004) Components of the residential environment and socio-demographic characteristics of the elderly. J Hous Elder 18(1):25-49. https://doi.org/10.1300/J081v18n01_03 
34. McCarthy KF (1976) The household life cycle and housing choices. Pape Reg Sci Assoc 37(1):55-80. https://doi.org/10.1 007/BF01941422

35. Du RY, Kamakura W (2006) Household Life Cycles and Lifestyles in the United States. J Market Res 43(1):121-132. https:// doi.org/10.1509/jmkr.43.1.121

36. Fernandez JAD, de Oliveira R, Heineck LF (2008) Family life cycle and the planning of multi family housing, in Proceedings of the inaugural construction management and economics 'Past, Present and Future' conference CME25, 16-18 July 2007. University of Reading, UK

37. St. John C, Cosby V (1995) Life cycle differences in neighborhood satisfaction. Sociol Spectr 15(2):147-160

38. Speare A (1970) Home ownership, life cycle stage, and residential mobility. Demography 7(4):449-458. https://doi.org/1 $0.2307 / 2060237$

39. Grigolon A, Dane G, Rasouli S, Timmermans H (2014) Binomial random parameters logistic regression model of housing satisfaction. Procedia Environ Sci 22:280-287. https://doi.org/10.1016/j.proenv.2014.11.027

40. Groat LN, Wang D (2013) Architectural research methods. John Wiley \& Sons, Hoboken (NJ)

41. Hegazy IR (2021) The quality of life between theory and implementation in Egypt: the case of Al-Rehab City, Egypt. Ain Shams Eng J 12(2):2285-2296. https://doi.org/10.1016/j.asej.2020.09.010

42. Al-Rehab (2020) Al Rehab New Cairo, a new vision for living in Egypt. Talaat Moustafa Group Holding Company, Cairo

43. Johnson TP (2014) Snowball sampling: introduction. In: Wiley StatsRef: Statistics Reference Online

44. Ghaljaie F, Naderifar M, Goli H (2017) Snowball sampling: a purposeful method of sampling in qualitative research. Strides Dev Med Educ 14(3):1-6. https://doi.org/10.5812/sdme.67670

45. Grant JL, Scott DE (2012) Complete communities versus the Canadian dream: representations of suburban aspirations. Can J Urban Res 21(1):132-157

46. Burdyak A, Housing policy and household lifecycle in post-soviet Russia: changing priorities, SCIENTIFIC PAPERS of the Maria Skłodowska-Curie Warsaw Academy, Quarterly, 2, 48, 221-232, 2015.

47. Neulinger A, Radó M (2018) The impact of household life-cycle stages on subjective well-being: Considering the effect of household expenditures in Hungary. Int J Consum Stud 42(1):16-26. https://doi.org/10.1111/ijcs.12397

\section{Publisher's Note}

Springer Nature remains neutral with regard to jurisdictional claims in published maps and institutional affiliations.

\section{Submit your manuscript to a SpringerOpen ${ }^{\circ}$ journal and benefit from:}

- Convenient online submission

- Rigorous peer review

- Open access: articles freely available online

- High visibility within the field

- Retaining the copyright to your article

Submit your next manuscript at $\boldsymbol{\nabla}$ springeropen.com 